\title{
Environmental Application of Telon Blue AGLF Adsorption on Sunflower Pulp: A Response Surface Methodology Approach and Kinetic Study
}

\author{
Ferda Gönen and Esra Köylü \\ Chemical Engineering Department, Mersin University, Çiftlikköy, 33343 Mersin, Turkey \\ Correspondence should be addressed to Ferda Gönen; gonenf74@gmail.com
}

Received 2 October 2015; Revised 26 January 2016; Accepted 3 February 2016

Academic Editor: Ángeles V. Del Río

Copyright ( 2016 F. Gönen and E. Köylü. This is an open access article distributed under the Creative Commons Attribution License, which permits unrestricted use, distribution, and reproduction in any medium, provided the original work is properly cited.

\begin{abstract}
The adsorptive removal of Telon Blue AGLF (TB AGLF) from aqueous solution using sunflower pulp was studied. The effects of $\mathrm{pH}$, adsorbent dose, temperature, and initial dye concentration on the adsorption capacity and the removal \% of TB AGLF were investigated. Experimental results showed that sunflower pulp was excellent agroindustrial adsorbent with maximum dye removal efficiency of $97.22 \%$ for a very short time (under conditions of $100 \mathrm{mg} \mathrm{L}^{-1}$ initial dye concentration, $\mathrm{pH}=3, \mathrm{~T}=50^{\circ} \mathrm{C}$, and $1 \mathrm{~g} \mathrm{~L}$ of adsorbent dose). The binary effects of initial dye concentration and temperature on the adsorption properties of sunflower pulp were analysed by RSM and two model equations for predicting adsorption capacity and dye removal \% of pulp because arbitrarily chosen initial dye concentration and temperature were developed by using response surface methodology (RSM). Experimental values of the adsorption capacity and dye removal \% were in good agreement with the predicted values by the improved models. Adsorption experiments and kinetic regression results indicated that the experimental data were well defined with pseudo-secondorder kinetic model.
\end{abstract}

\section{Introduction}

Many harmful organic and inorganic substances such as aromatic compounds, heavy metals, and dyes are present in industrial wastewater. The effluents of the textile, leather, printing, laundry, tannery, rubber, plastic, painting, and other industries produce colored dyes which are known as major water pollutants [1]. Dye colored water is highly visible and have the effects of reduction of light penetration and gas solubility in water [2]. Synthetic dyes consist of complex aromatic structures which supply them with physicochemical, thermal, and optical properties. A large number of dyes and pigments have toxic property for nature with suspected carcinogenic and mutagenic effects that affect aquatic biota and humans [3]. Due to all of the detrimental effects, industrial effluents containing dyes need to be treated before being discharged to the aquatic environment [4]. Practically, the treatment of textile wastewater by conventional methods has been found to be ineffective for many wastewater treatment facilities. Traditional textile dyeing process, such liquidliquid extraction, uses a lot of untreated water, which is then discharged to the environment as water containing dye stuff chemicals. The simplest and the most cost effective treatment method for the removal of color dyes from wastewater must be determined before contacting with unpolluted natural water sources [5]. Coagulation, flocculation, ion exchange, membrane separation, and oxidation are some different treatment technologies which are used to remove dyes from waste effluents [6]. But, several limitations of these methods are high-energy consumption, incomplete pollutant removal, and production of toxic waste products that require further treatment method [7]. Some researchers have demonstrated that biological treatment of textile wastewater has resistance to degradation due to the presence of biological inert matter combined with high molecular weight dyestuff [8]. In literature, it has been proved that, of the 18 azo dyes investigated, 11 compounds passed through the activated sludge process practically untreated, 4 (Acid Blue 113, Acid 
Red 151, Direct Violet 9, and Direct Violet 28) were adsorbed on the waste activated sludge, and only 3 (Acid Orange 7, Acid Orange 8, and Acid Red 88) were biodegraded [9]. On the other hand, physical adsorption is effective in removing nonbiodegradable pollutants. When it is compared in terms of efficiency and ease of use, adsorption was known as the more preferable technique for wastewater treatment than conventional treatment processes [10]. In addition to being efficient and easy to operate, this technique is cost effective and eco-friendly for dye removal and also insensitive to toxic substances [11]. In removal processes of many pollutants by adsorption, activated carbon is known as the most widely used adsorbent. Due to the reasons of the expensive production and regeneration, it is still considered as expensive $[12,13]$. Therefore, cheaper materials such as the solid wastes obtained from the agricultural industry are needed for adsorption [14]. The advanced research has been carried out to examine the possibility of using a number of low cost substances including agroindustrial waste as adsorbents, such as nuts, peanuts, olive wastes, sugar cane bagasse, banana, orange peels, tea leaves, coconut bunch waste, rice, and wheat waste [15]. Currently, the use of locally produced sunflower meal as an adsorbent can be quite attractive and supportive for socioeconomic development. The main purpose of this study was twofold: firstly investigate TB AGLF adsorption properties of sunflower pulp as a function of $\mathrm{pH}$, adsorbent dosage, initial dye concentrations, and temperature in a batch system and secondly observe if the adsorption capacity and removal \% could be modelled by using RSM as a function of initial dye concentration and temperature for bringing a new perspective to the wastewater treatment strategies. In the study, the reason of selection of TB AGLF as a model dye material is the extended use of this dye in textile industry and potential harmful effect to the environment. On the other hand, sunflower pulp is a low cost agroindustrial waste residue found in abundance. It is used as animal feed and it is composed of $32 \%$ and more than $20 \%$ of crude protein and fiber substances, respectively. Functional groups which play a major role in the adsorption of metal ions and dyes from wastewaters are carboxyl, hydroxyl, sulfhydryl, and amide present on the surface of organic sorbents including agricultural residues [16-18]. The present study would be the first report describing the effects of $\mathrm{pH}$, initial dye concentration, adsorbent dosage and temperature on TB AGLF adsorption, and mechanism of TB AGLF adsorption on sunflower pulp.

\section{Material and Methods}

2.1. Adsorbent. Sunflower pulp is one of the most produced pulp in Turkey. Sunflower meal is the residual after removal of the oil from sunflower seed oil. There are two types of sunflower pulp in the market. One of them is mixed pulp that contains low crude protein and $2-3 \%$ oils with high crude cellulose content due to their more shelled. The oil rate in this type of pulp does not exceed $1.5 \%$. In addition, its protein content is higher than that of the other type. The chemical structure of sunflower pulp is given in Table 1 .

In this experimental study, the waste pulp of sunflower remaining from the sunflower oil industry was obtained from
TABLE 1: The chemical structure of sunflower pulp.

\begin{tabular}{lccc}
\hline Content & $\begin{array}{c}\text { Partially } \\
\text { shelled (\%) }\end{array}$ & $\begin{array}{c}\text { Shelled } \\
(\%)\end{array}$ & $\begin{array}{c}\text { Nonshelled } \\
(\%)\end{array}$ \\
\hline Water & 12 & 15.7 & 10.8 \\
Crude oil & 1.4 & 1.1 & 4.9 \\
Crude protein & $31-35$ & 49.5 & 19.6 \\
Digestible protein & $28-32$ & 45 & 16.3 \\
Nitrogen-free extract & 28 & 28.6 & 27 \\
substances & 60 & 70.8 & 35.6 \\
Total digestible nutrients & 19.6 & 5.4 & 35.9 \\
Crude fiber & 5.7 & 5.9 & 5.6 \\
Crude ash & - & 0.26 & - \\
Calcium & - & 1.22 & - \\
Phosphorus & & &
\end{tabular}<smiles>CCCCOS(=O)(=O)c1cc(NCCC)c(C)cc1Nc1cc2c(nc3ccc(N(CC)CC)cc3[n+]2-c2cc(C)c(S(=O)(=O)OCC)cc2C)c2ccccc12</smiles>

FIGURE 1: The molecular structure of TB AGLF.

TABLE 2: Some essential properties of TB AGLF.

\begin{tabular}{lc}
\hline CAS & $6378-87-6$ \\
\hline Molecular weight & 735.85 \\
Synonyms & Acid Blue 121, Navazol Acid Blue GL \\
Molecular formula & $\mathrm{C}_{37} \mathrm{H}_{38} \mathrm{~N}_{5} \mathrm{NaO}_{6} \mathrm{~S}_{2}$ \\
$\lambda_{\max }$ & $610 \mathrm{~nm}$ \\
\hline
\end{tabular}

Aves Oil Factory, Mersin, Turkey. The collected sunflower pulp was washed with tap water to remove surface adhered particles and water soluble materials. Then, it was sprayed with distilled water and dried in an oven at $100^{\circ} \mathrm{C}$ to a constant weight. After grinding process, it was sieved to get the adsorbent having size $\leq 500 \mu \mathrm{m}$ and stored in dry containers for use in all experiments.

2.2. Preparation of Dye Stock Solution. TB AGLF dye (purchased from Sigma Aldrich Co.) was used in our experiments. Some essential properties and the molecular structure of TB AGLF dye are given in Table 2 and Figure 1. All chemicals used in the experiments were of reagent grade. Doubly distilled water was used for preparation of all solutions. Dye solutions with the concentration range of $25-500 \mathrm{mg} \mathrm{L}^{-1}$ were prepared by diluting $1.0 \mathrm{~g} \mathrm{~L}^{-1}$ of stock solution. Diluted or concentrated $\mathrm{H}_{2} \mathrm{SO}_{4}$ and $\mathrm{NaOH}$ solutions were used for the required value the $\mathrm{pH}$ of each solution. 
2.3. Experimental System and Analysis. $250 \mathrm{~mL}$ glassstoppered round-bottom flasks immersed in a thermostatic shaker bath were used in the adsorption experiments. The bottles were filled with $150 \mathrm{~mL}$ of dye solution at desired $\mathrm{pH}$, concentration, and temperature. The required amount of adsorbent was added and the flasks were placed on a shaker with $150 \mathrm{rpm}$ agitation speed for $4 \mathrm{~h}$. Then, samples were collected at predetermined time intervals. The supernatant was centrifuged for $3 \mathrm{~min}$ at $3000 \mathrm{rpm}$ to determine the final concentration of dye in the solution at the end of each time interval. UV/vis spectrophotometer was used for analysing the dye concentration in the solution at the maximum absorption wavelength $(\lambda=610 \mathrm{~nm})$.

The amounts of TB AGLF adsorbed at equilibrium $q_{e}\left(\mathrm{mg} \mathrm{g}^{-1}\right)$ and dye removal \% were determined as follows:

$$
\begin{aligned}
q_{e} & =\frac{\left(C_{0}-C_{e}\right) V}{m}, \\
\text { Removal } \% & =\left(\frac{\left(C_{0}-C_{e}\right) V}{C_{0}}\right) \times 100,
\end{aligned}
$$

where $q_{e}$ is the equilibrium concentration of TB AGLF on the adsorbent $\left(\mathrm{mg} \mathrm{g}^{-1}\right), C_{0}$ is the initial concentration of the TB AGLF solution $\left(\mathrm{mg} \mathrm{L}^{-1}\right), C_{e}$ is the equilibrium concentration of the TB AGLF solution $\left(\mathrm{mg} \mathrm{L}^{-1}\right), m$ is the mass of adsorbent (g), and $V$ is the volume of TB AGLF solution (L).

\subsection{Experimental Design and Statistical Analysis. The tra-} ditional method of studying with one variable at a time is not able to represent the combined effects of all the factors involved. The response surface methodology (RSM) can be used as an interesting strategy to implement process conditions which lead to optimal response by performing a minimum number of experiments. This method consists of mathematical and statistical techniques used for developing, improving, and optimizing the processes and it is applied to evaluate several influencing factors in the presence of complex interactions. RSM methodology is often used in the treatment technology to demonstrate the effects of operational conditions on the removal process or to decide a satisfied operation region.

When the effects of adsorption parameters ( $\mathrm{pH}$, adsorbent dosage, initial dye concentrations, and temperature) on dye uptake capacity and dye removal \% were examined, experimental results indicated that the level of TB AGLF adsorption was highly dependent on the initial TB AGLF concentration and temperature. So, the initial TB AGLF concentration and temperature were selected as the independent variables and dye uptake capacity and removal \% properties of sunflower pulp were selected as response. $q$ and removal \% of TB AGLF according to initial dye concentration and temperature affecting dye removal properties were modelled by means of the quadratic polynomial model $[19,20]$.

Response surface methodology (RSM) technique can be preferable to evaluate the relationships between the response and the independent variables with a minimum number of trails according to special experimental designs based on factorial designs. In this study, TB AGLF dye concentration and temperature in the adsorption medium were determined as independent variables $\left(X_{1}\right.$ and $\left.X_{2}\right)$ and TB AGLF dye uptake capacity and dye percentage removal were selected as two response variables $\left(Y_{1}\right.$ and $\left.Y_{2}\right)$. The low, centre, and high levels of each variable are designated as $-1,0$, and +1 , respectively. The first independent variable (initial dye concentration) was varied over two levels (100 and $500 \mathrm{mg} \mathrm{L}^{-1}$ ) relative to the centre point $\left(300 \mathrm{mg} \mathrm{L}^{-1}\right)$ while the second independent variable (temperature) was changed over two levels $\left(30\right.$ and $\left.50^{\circ} \mathrm{C}\right)$ relative to the centre point $\left(40^{\circ} \mathrm{C}\right)$. In order to study the combined effects of these variables on the responses, 13 sets of experiments with appropriate combinations of TB AGLF dye and temperature were organizied using Box-Wilson statistical method to fit a second-order polynomial model. When the critical ranges of independent variables (dye concentration and temperature) were decided, preliminary experiments based on the literature review were made [21, 22]. To the best of our knowledge, there is no information about applying RSM to investigate the effects of process parameters such as initial TB AGLF concentrations and temperature on the sunflower pulp adsorption.

In our study, statistical analyses were performed using Stat-Ease software (Design-Expert ${ }^{\circledR}$ Software Version 9-StatEase, Inc.). Some researchers described the theoretical consideration and model equations in the literature [23-25].

In order to determine the statistical significance of the model equation and the goodness of fit of the model, the coefficient determination $\left(R^{2}\right)$ and $F$-test analysis of variance (ANOVA) were used. According to the ANOVA, the representation of most of the variation in the response by the regression equation was checked by the big value of $F$. A value of $P$ is used to estimate whether $F$ is large enough to show statistical significance. If the model is statistically significant, a value of $P$ is lower than 0.05 [19].

2.5. Adsorption Kinetic Studies. The adsorption kinetic study determines the rate of adsorption of the adsorbent. So, it is very important in process design. In addition, the mechanism that controls the adsorption and the rate-limiting step is determined by kinetic study. The experimental results obtained from this study were used to investigate the kinetics of Telon Blue AGLF adsorption by various kinetics models. The kinetic data were firstly fitted into the pseudo-first-order and then the pseudo-second-order models.

Pseudo-First-Order Kinetic Model. Lagergren proposed the pseudo-first-order equation that expressed the rate constant of adsorption [26]:

$$
\ln \left(q_{e}-q_{t}\right)=\ln q_{e}-k_{1} t
$$

where $q_{e}$ and $q_{t}\left(\mathrm{mgg}^{-1}\right)$ are the amounts of TB AGLF $\left(\mathrm{mg} \mathrm{g}^{-1}\right)$ at equilibrium and at time $t(\mathrm{~h})$, respectively. $k_{1}$ is the adsorption rate constant $\left(\mathrm{h}^{-1}\right)$. 


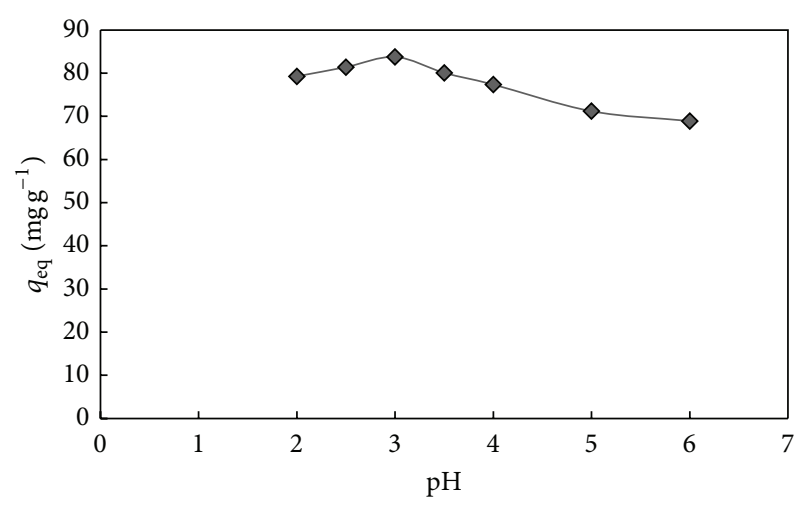

FIgURE 2: The effect of initial $\mathrm{pH}$ on the adsorption of TB AGLF by sunflower pulp $\left(T: 25^{\circ} \mathrm{C}, C_{0}: 100 \mathrm{mg} \mathrm{L}^{-1}, X: 1.0 \mathrm{~g} \mathrm{~L}^{-1}\right.$, and agitation rate: $150 \mathrm{rpm})$.

For the pseudo-first-order kinetic model, the kinetic parameters can be determined by the plots of $\left(q_{e}-q_{t}\right)$ versus $t$ at different initial dye concentrations.

Pseudo-Second-Order Kinetic Model. Ho and McKay proposed the pseudo-first-order model [27]. This model equation is expressed as

$$
\frac{t}{q_{t}}=\frac{1}{k_{2} q_{e}^{2}}+\frac{t}{q_{e}},
$$

where $k_{2}\left(\mathrm{~g} \mathrm{mg}^{-1} \mathrm{~h}^{-1}\right)$ is the rate constant of second-order model.

For the pseudo-second-order kinetic model, the kinetic parameters can be evaluated by the plots of $t / q_{t}$ versus $t$ at different initial dye concentrations.

\section{Results and Discussion}

3.1. Effect of Solution $p H$. The adsorption capacity of adsorbent is strongly affected by the solution $\mathrm{pH}$. In order to observe this effect, TB AGLF adsorption using sunflower pulp was studied in the $\mathrm{pH}$ range of 3-8, using an initial dye concentration of $100 \mathrm{mg} \mathrm{L}^{-1}$ and an adsorbent amount of $1 \mathrm{~g} \mathrm{~L}^{-1}$ at $25^{\circ} \mathrm{C}$. Figure 2 indicated that the increase of $\mathrm{pH}$ from 2 to 3 causes an increase in $\mathrm{H}^{+}$ion concentration in the adsorption medium, and the surface of the pulp obtains a positive charge by the adsorption of $\mathrm{H}^{+}$ions. When the pulp surface is positively charged at $\mathrm{pH}=3$, a significantly strong electrostatic attraction occurred between the positively charged sites. As the pulp surface site is negative, the adsorbent surface becomes predominantly negatively charged, leading to a decrease in the adsorption capacity due to the competition between excess $\mathrm{OH}^{-}$ions and the anionic TB AGL dye molecule for the adsorption sites. In literature, similar results are observed for the adsorption of Congo red on cashew nut shell [28], sunflower seed hull [29], soy meal hull [30].

From Figure 2, it is seen that the adsorption of TB AGLF was maximum at $\mathrm{pH} 3.0\left(q_{\mathrm{eq}}=85.07 \mathrm{mg} \mathrm{g}^{-1}\right.$, removal \%= 86.09) and the other adsorption experiments were performed at this optimum $\mathrm{pH}$ value.
TABLE 3: The effect of adsorbent dose on the equilibrium uptake capacities and removal \% of TB AGLF by sunflower pulp.

\begin{tabular}{lcccc}
\hline$X_{0}\left(\mathrm{~g} \mathrm{~L}^{-1}\right)$ & 0.5 & 1.0 & 2.0 & 3.0 \\
\hline$q_{\text {eq }}\left(\mathrm{mg} \mathrm{g}^{-1}\right)$ & 148.53 & 85.07 & 42.98 & 27.77 \\
Removal \% & 76.40 & 86.09 & 85.33 & 84.18 \\
\hline
\end{tabular}

3.2. Effect of Adsorbent Dosage. The adsorption of TB AGLF by sunflower pulp was studied by using different adsorbent doses $\left(0.50,1.0,2.0\right.$, and $\left.3.0 \mathrm{~g} \mathrm{~L}^{-1}\right)$ for the initial dye concentration of $100 \mathrm{mg} \mathrm{L}^{-1}$ at $25^{\circ} \mathrm{C}$ and $\mathrm{pH}$ 3.0. It is clear from Table 3 that the adsorbent dose was increased, and the adsorption capacity was decreased.

The explanation of this phenomenon is that adsorption sites remain unsaturated during the adsorption reaction whereas the number of sites available for adsorption site increases by increasing the adsorbent dose [31]. It is evident that the particle aggregation is present. In the literature, some investigations including other types of dye-sorbent systems mentioned and criticized the similar behavior for the effect of adsorbent concentrations on TB AGLF dye sorption capacity $[32,33]$. In this study, the maximum adsorption capacity of $148.53 \mathrm{mg} \mathrm{g}^{-1}$ was obtained with adsorbent dose of $0.5 \mathrm{~g}$, initial dye concentration of $100 \mathrm{mg} / \mathrm{L}$, and initial solution $\mathrm{pH}$ of 3.0. The TB AGLF removal \% by sunflower pulp was determined as $76.40 \%$ at the same conditions. This removal value was higher than that reported in a literature. Usluoglu et al. [34] presented the TB AGLF removal \% value of $33.0 \%$ for corncob activated carbon adsorption [34].

\subsection{Effect of Initial TB AGLF Concentration on Temperature-} Dependent Adsorption. The effect of initial dye concentration on the adsorption capacity of sunflower pulp was investigated between 100 and $500 \mathrm{mg} \mathrm{L}^{-1}$ at three different temperatures. If the concentration and temperature ranges of TB AGLF were compared with literature, similar results were seen. In 2016, Karimifard and Moghaddam [35] studied RB19 removal at constant dye concentration of $100 \mathrm{mg} \mathrm{L}^{-1}$. They examined the combined effects of $\mathrm{pH}$, initial dye concetration, and adsorbent dose by RSM model. Similarly, in 2009, Srinivasan and Murthy [36] used RSM analysis to evaluate response variable (decolorization \%) as a function of the independent variables such as glucose and ammonium chloride concentrations in terms of coded values. When decolorization $\%$ of reactive red dye is examined, the concentration range was varied over two levels ( 250 and $500 \mathrm{mg} \mathrm{L}^{-1}$ ). In this study, $R^{2}$ value of regressions model equation shows a good fit of the model with experimental data. In 2010, Singh et al. [22] examined the effects of four independent variables, temperature $\left(10-50^{\circ} \mathrm{C}\right)$, initial $\mathrm{pH}$ of solution (2-10), initial dye concentration (140$\left.220 \mathrm{mg} \mathrm{L}^{-1}\right)$, and adsorbent dose $\left(1-5 \mathrm{~g} \mathrm{~L}^{-1}\right)$ on Rhodamine $\mathrm{B}$ removal. It is clear from the literature search that the critical ranges of independent variables consist of appropriate and realistic combinations of dye concentration and temperature.

The results for the effect of initial TB AGLF concentration and the temperature are shown in Table 4. As it is seen from Table 4, the equilibrium sorption capacity of sunflower 
TABLE 4: Effect of initial TB AGLF dye concentration and temperature on the equilibrium capacity and removal \% of sunflower pulp.

\begin{tabular}{|c|c|c|c|c|c|c|c|c|}
\hline \multicolumn{3}{|c|}{$30^{\circ} \mathrm{C}$} & \multicolumn{3}{|c|}{$40^{\circ} \mathrm{C}$} & \multicolumn{3}{|c|}{$50^{\circ} \mathrm{C}$} \\
\hline$C_{0}\left(\mathrm{mg} \mathrm{L}^{-1}\right)$ & $q_{\mathrm{eq}}\left(\mathrm{mg} \mathrm{g}^{-1}\right)$ & Removal \% & $C_{0}\left(\mathrm{mg} \mathrm{L}^{-1}\right)$ & $q_{\mathrm{eq}}\left(\mathrm{mg} \mathrm{g}^{-1}\right)$ & Removal \% & $C_{0}\left(\mathrm{mg} \mathrm{L}^{-1}\right)$ & $q_{\mathrm{eq}}\left(\mathrm{mg} \mathrm{g}^{-1}\right)$ & Removal \% \\
\hline 97.94 & 86.62 & 88.44 & 100.29 & 95.51 & 95.23 & 100.59 & 97.79 & 97.22 \\
\hline 273.13 & 194.85 & 82.17 & 228.67 & 207.35 & 90.67 & 223.52 & 205.88 & 92.10 \\
\hline 318.01 & 248.16 & 78.03 & 305.14 & 261.76 & 85.78 & 303.67 & 265.44 & 87.41 \\
\hline 492.65 & 343.75 & 69.78 & 498.16 & 363.97 & 73.06 & 501.84 & 393.38 & 78.39 \\
\hline
\end{tabular}

pulp for dye increased notably with increasing initial dye concentration up to $500 \mathrm{mg} \mathrm{L}^{-1}$ and increasing temperature up to $50^{\circ} \mathrm{C}$. Then, a slight increase in initial dye concentration at any of the temperature studied did not change the equilibrium sorption capacity. In other words, equilibrium sorption capacity showed a saturation trend at higher dye concentrations due to a finite number of surface binding sites. At $25^{\circ} \mathrm{C}$, when the initial dye concentration increased from 118.53 to $473.06 \mathrm{mg} \mathrm{L}^{-1}$, the equilibrium capacity of adsorbent increased from 114.87 to $269.40 \mathrm{mg} \mathrm{g}^{-1}$. The temperature also affected the equilibrium dye capacity as shown in Table 4. When the temperature was raised from 30 to $50^{\circ} \mathrm{C}$, the uptake capacity increased from 86.62 to $97.79 \mathrm{mg} \mathrm{g}^{-1}$ at $100 \mathrm{mg} \mathrm{L}^{-1}$ initial dye concentration. From the same table, removal $\%$ of dye showed the opposite trend and decreased with the increasing initial dye concentration. With the rise in temperature from 30 to $50^{\circ} \mathrm{C}$, removal \% of dye increased from 88.44 to $97.22 \%$ for $100 \mathrm{mg} \mathrm{L}^{-1}$ initial dye concentration, respectively. It can be said that adsorption becomes independent of initial concentration at lower concentrations. The reason of this phenomenon is that the ratio of initial number of dye ions to the available sorption sites is low. In the case of higher concentrations, because the available sites of adsorption become fewer, the removal of dye depends on the initial concentration.

\subsection{Response Surface Estimation for the Combined Effects of} Initial Dye Concentration and Temperature on the Equilibrium Sorption Capacity and Removal Percentage of Dye. The purpose of this study is not only to examine the combined effects of initial concentration and temperature on dye adsorption properties of the sunflower pulp, but also to find the best models that describe dye removal process.

In this analysis, independent variables were initial dye concentration and temperature in the adsorption medium. Dependent output response variables were the equilibrium sorption capacity and removal percentage of dye. In order to examine the combined effects of independent variables on the responses, 13 sets of experiments with appropriate combinations of initial dye concentrations and temperatures were carried out according to Box-Wilson statistical method. The first independent variable (initial dye concentration) was varied over two levels (100 and $500 \mathrm{mg} \mathrm{L}^{-1}$ ) relative to the center point $\left(300 \mathrm{mg} \mathrm{L}^{-1}\right)$, while the second independent variable (temperature) was changed over two levels (30 and $\left.50^{\circ} \mathrm{C}\right)$ relative to the center point $\left(40^{\circ} \mathrm{C}\right)($ Table 5$)$.
TABLE 5: Experimental range and levels of independent process variables.

\begin{tabular}{lcccc}
\hline \multirow{2}{*}{ Independent variables } & \multirow{2}{*}{ Design variables } & \multicolumn{3}{c}{ Range and levels } \\
& & -1 & 0 & +1 \\
\hline$C_{0}\left(\mathrm{mg} \mathrm{L}^{-1}\right)$ & $X_{1}$ & 100 & 300 & 500 \\
$T\left({ }^{\circ} \mathrm{C}\right)$ & $X_{2}$ & 30 & 40 & 50 \\
\hline
\end{tabular}

In order to estimate the responses of equilibrium sorption capacities and removal \% of dye numerically and the graphical analysis of the model, the statistical software package Design-Expert 9 was used for the experimental data evaluation. For the purpose of the convenience of fit of the model, the coefficient determination $\left(R^{2}\right)$ and the analysis of variances (ANOVA) were used. The experimental findings of equilibrium sorption capacity and removal \% of dye were adapted to a second-order quadratic equation, giving two numerical correlations to predict the responses of equilibrium sorption capacity and removal percentages of dye:

$$
\begin{aligned}
q= & -40.694+0.932 X_{1}+1.662 X_{2}+4.807 E \\
& -003 X_{1} X_{2}-7.328 E-004 X_{1}^{2} \\
& -0.022 X_{2}^{2} \\
\text { Removal \% } & 50.484-0.041 X_{1}+1.986 X_{2}-2.25 E \\
& -005 X_{1} X_{2}-1.227 E-005 X_{1}^{2} \\
& -0.019 X_{2}^{2}
\end{aligned}
$$

where $X_{1}$ and $X_{2}$ are initial dye concentration $\left(\mathrm{mg} \mathrm{L}^{-1}\right)$ and temperature $\left({ }^{\circ} \mathrm{C}\right)$, respectively. The values of $q$ and dye removal \% experimentally obtained and predicted from the related empirical models are listed in Table 6 . Table 6 indicated that, for both independent variables, the calculated values of $q$ and removal $\%$ agreed very well with the predicted values of $q$ and removal $\%$ at all concentration-temperature combinations studied.

In order to assess the accuracy of the model, a different set of independent experiments was used.

The results for the experimentally obtained and predicted values from the related empirical models at different concentration-temperature combinations are listed in Table 7. As it is seen from Table 7 , the calculated values 
TABLE 6: $q$ and removal \% values experimentally determined and predicted from RSM.

\begin{tabular}{|c|c|c|c|c|c|}
\hline$C_{0}\left(\mathrm{mg} \mathrm{L}^{-1}\right)$ & $T\left({ }^{\circ} \mathrm{C}\right)$ & $q_{\text {experimental }}\left(\mathrm{mg} \mathrm{g}^{-1}\right)$ & $q_{\text {predicted }}\left(\mathrm{mg} \mathrm{g}^{-1}\right)$ & Removal $_{\text {experimental }} \%$ & Removal $_{\text {predicted }} \%$ \\
\hline 500 & 30 & 343.75 & 344.27 & 69.78 & 69.06 \\
\hline 100 & 50 & 97.79 & 97.31 & 97.22 & 97.95 \\
\hline 300 & 40 & 261.76 & 261.92 & 85.78 & 85.85 \\
\hline 300 & 40 & 261.76 & 261.92 & 85.78 & 85.85 \\
\hline 300 & 40 & 261.76 & 261.92 & 85.78 & 85.85 \\
\hline 100 & 30 & 86.62 & 89.66 & 88.43 & 88.67 \\
\hline 100 & 40 & 95.51 & 95.69 & 96.23 & 95.21 \\
\hline 500 & 40 & 363.97 & 369.53 & 73.06 & 75.51 \\
\hline 300 & 40 & 261.76 & 261.92 & 85.78 & 85.85 \\
\hline 300 & 30 & 248.16 & 246.28 & 78.03 & 79.36 \\
\hline 500 & 50 & 393.38 & 390.38 & 78.39 & 78.15 \\
\hline 300 & 40 & 261.76 & 261.92 & 85.78 & 85.85 \\
\hline 300 & 50 & 265.44 & 273.16 & 87.41 & 88.54 \\
\hline
\end{tabular}

of $q$ and removal \% agreed very well with the predicted values of $q$ and removal $\%$ at all concentration-temperature combinations studied.

Tables 8 and 9 show the results of the quadratic model for $q$ and removal $\%$ in the form of analysis of variance (ANOVA).

The associated Prob. $>F$ value for the each model $(0.0001$ for $q$ and 0.0001 for dye removal \%) is lower than 0.05 (i.e., $a=0.05$ or $95 \%$ confidence). This result pointed out that it is statistically significant at $99.99 \%$ confidence level for both $q$ and \% dye removal values. As seen from the tables, $R^{2}$ values were almost equal to 1.0. This means that there is a high correlation between the experimental and predicted values. Therefore, regression model presents the best expression of the relationship between the independent variables (initial dye concentration and temperature) and the responses ( $q$ and $\%$ dye removal). 99.91 and $98.92 \%$ of the sample variation for $q$ and dye removal \% means that the model did not explain only about 0.09 and $1.08 \%$ of sample variation for $q$ and $\%$ dye removal, respectively. The statistical significance of the quadratic models for the responses was shown by the investigation of the fit summaries output. Statistical models derived from RSM demonstrated that these equations may be useful for further analysis in this experimental range.

Figures 3 and 4, respectively, show the three-dimensional response surface graphs and two-dimensional contour plots of the quadratic model for $q$ and \% dye removal. From the figures, the equilibrium sorption capacity of sunflower pulp for TB AGLF dye increased with increasing initial dye concentration up to $500 \mathrm{mg} \mathrm{L}^{-1}$ and with increasing temperature up to $50^{\circ} \mathrm{C}$. On the other hand, it was seen that higher removal percentages were obtained at lower initial dye concentration for all temperatures. The best value of equilibrium adsorption capacity and dye removal \% occurred close to the upper point indicating the values of $500 \mathrm{mg} \mathrm{L}^{-1}$ (for adsorption capacity), $100 \mathrm{mg} \mathrm{L}^{-1}$ (for removal \%) $\mathrm{TB}$ AGLF dye concentrations and $50^{\circ} \mathrm{C}$ (in both adsorption capacity and removal \%).
3.5. Kinetic Studies for TB AGLF Adsorption. The obtained kinetic parameters, the values of the calculated amount of dye adsorbed at equilibrium $\left(q_{e, \mathrm{cal}}\right)$, pseudo-first-order adsorption rate constant $(k)$, and pseudo-second-order adsorption rate constant $(k)$ of TB AGLF adsorption, are presented in Table 10. According to the experimental results, the Lagergren pseudo-first-order kinetic model data do not agree with the straight line for all investigated dye concentrations, indicating the low values of the correlation coefficients. Conversely, the pseudo-second-order kinetic was determined to best fit the experimental data over the whole experimental range as indicating that the fitting of this model was admissable. According to the presented results, pseudo-second-order kinetic model can be used to estimate the amount of dye uptake at different contact time intervals and at equilibrium. As it is seen from Table 10, it was noticed that, for the examined conditions, the prediction certainty of the pseudosecond-order expression is better than that of pseudo-firstorder model.

\section{Conclusion}

The present study showed that sunflower pulp, a low cost agricultural waste, exhibited high adsorption efficiency for TB AGLF dye with maximum adsorption capacity of $97.79 \mathrm{mg} \mathrm{g}^{-1}$ under conditions of $100 \mathrm{mg} \mathrm{L}^{-1}$ initial dye concentration, $\mathrm{pH}=3, \mathrm{~T}=50^{\circ} \mathrm{C}$, and $1 \mathrm{~g} \mathrm{~L}^{-1}$ of adsorbent dose. According to the experimental results, the adsorption process was strongly $\mathrm{pH}$ dependent. Because of the presence of multiple functional groups present on the pulp surface, adsorption of TB AGLF was observed to be very fast. The process of TB AGLF dye adsorption on sunflower pulp proceeds via pseudo-second-order kinetics. In this study, the mathematical models for the $q$ and removal \% for the adsorption of Telon Blue AGLF were developed. Two model equations for dye adsorption present a good idea of the dye uptake capacity and \% removal with respect to initial TB AGLF concentration and temperature within appropriate combinations of $\mathrm{TB}$ AGLF and temperature ranges studied. Although they can 
TABLE 7: Experimentally determined and predicted $q$ and removal \% values at different concentration-temperature combinations to assess the accuracy of the model.

\begin{tabular}{|c|c|c|c|c|c|}
\hline$C_{0}\left(\mathrm{mg} \mathrm{L}^{-1}\right)$ & $T\left({ }^{\circ} \mathrm{C}\right)$ & $q_{\text {experimental }}\left(\mathrm{mg} \mathrm{g}^{-1}\right)$ & $q_{\text {predicted }}\left(\mathrm{mg} \mathrm{g}^{-1}\right)$ & Removal $_{\text {experimental }} \%$ & Removal $_{\text {predicted }} \%$ \\
\hline 25 & 25 & 17.06 & 12.95 & 82.86 & 87.21 \\
\hline 50 & 25 & 37.13 & 37.88 & 83.89 & 86.15 \\
\hline 75 & 25 & 59.71 & 61.90 & 84.15 & 85.07 \\
\hline 100 & 25 & 85.07 & 85.00 & 86.09 & 83.98 \\
\hline 200 & 25 & 152.57 & 168.23 & 79.05 & 79.46 \\
\hline 300 & 25 & 218.75 & 236.82 & 75.80 & 74.69 \\
\hline 500 & 25 & 295.96 & 330.02 & 62.16 & 64.41 \\
\hline 25 & 30 & 21.10 & 15.81 & 88.31 & 91.91 \\
\hline 50 & 30 & 42.35 & 41.34 & 86.88 & 90.85 \\
\hline 75 & 30 & 64.56 & 65.96 & 88.06 & 89.77 \\
\hline 100 & 30 & 86.62 & 89.66 & 88.44 & 88.67 \\
\hline 200 & 30 & 194.85 & 175.30 & 82.17 & 84.14 \\
\hline 300 & 30 & 248.16 & 246.29 & 78.03 & 79.36 \\
\hline 500 & 30 & 343.75 & 344.30 & 69.78 & 69.06 \\
\hline 25 & 40 & 21.84 & 18.24 & 91.10 & 98.47 \\
\hline 50 & 40 & 46.25 & 44.97 & 93.32 & 97.40 \\
\hline 75 & 40 & 67.94 & 70.79 & 93.81 & 96.31 \\
\hline 100 & 40 & 95.51 & 95.69 & 95.23 & 95.21 \\
\hline 200 & 40 & 207.35 & 186.13 & 90.68 & 90.65 \\
\hline 300 & 40 & 261.76 & 261.93 & 85.78 & 85.85 \\
\hline 500 & 40 & 363.97 & 369.55 & 73.06 & 75.51 \\
\hline 25 & 50 & 21.32 & 18.24 & 93.25 & 98.47 \\
\hline 50 & 50 & 43.97 & 44.97 & 94.47 & 97.40 \\
\hline 75 & 50 & 69.78 & 70.79 & 95.76 & 96.31 \\
\hline 100 & 50 & 97.79 & 95.69 & 97.22 & 95.21 \\
\hline 200 & 50 & 205.88 & 186.13 & 92.11 & 90.65 \\
\hline 300 & 50 & 265.44 & 261.93 & 87.41 & 85.85 \\
\hline 500 & 50 & 393.38 & 369.55 & 78.39 & 75.51 \\
\hline
\end{tabular}

TABLE 8: Analysis of variance (ANOVA) for quadratic model for $q$.

\begin{tabular}{|c|c|c|c|c|c|}
\hline Sources of variation & Sum of squares & Degree of freedom & Mean square & $F$ value & Probability $>F$ \\
\hline Model & $1.167 E+005$ & 5 & 23346.13 & 1636.72 & $<0.0001$ \\
\hline Residual & 99.85 & 7 & 14.26 & & \\
\hline Lack of fit & 99.85 & 3 & 33.28 & & \\
\hline Pure error & 0.000 & 4 & 0.000 & & \\
\hline Total & $1.168 E+005$ & 12 & & & \\
\hline
\end{tabular}

$R^{2}=0.9991 ; \mathrm{CV}=3.78 \%$.

TABLE 9: Analysis of variance (ANOVA) for quadratic model for removal \%.

\begin{tabular}{|c|c|c|c|c|c|}
\hline Sources of variation & Sum of squares & Degree of freedom & Mean square & $F$ value & Probability $>F$ \\
\hline Model & 727.51 & 5 & 145.50 & 128.12 & $<0.0001$ \\
\hline Residual & 7.95 & 7 & 1.14 & & \\
\hline Lack of fit & 7.95 & 3 & 2.65 & & \\
\hline Pure error & 0.000 & 4 & 0.000 & & \\
\hline Total & 735.46 & 12 & & & \\
\hline
\end{tabular}

$R^{2}=0.9892 ; \mathrm{CV}=1.07 \%$. 


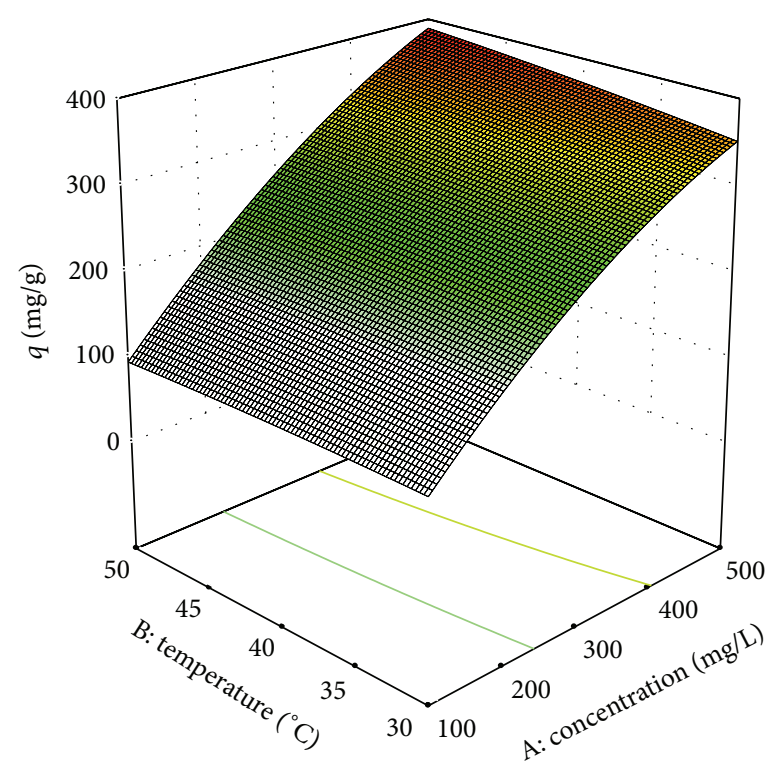

(a)

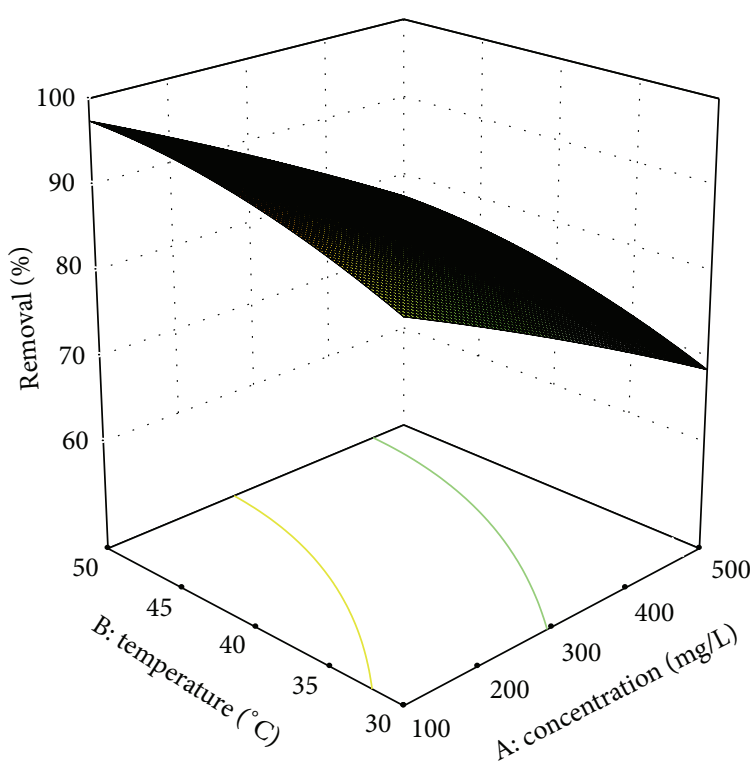

(b)

FIGURE 3: Three-dimensional response surface graphs: (a) combined effects of TB AGLF concentration and temperature on the adsorption capacity of sunflower pulp and (b) combined effects of TB AGLF concentration and temperature on percent TB AGLF removal by sunflower pulp.

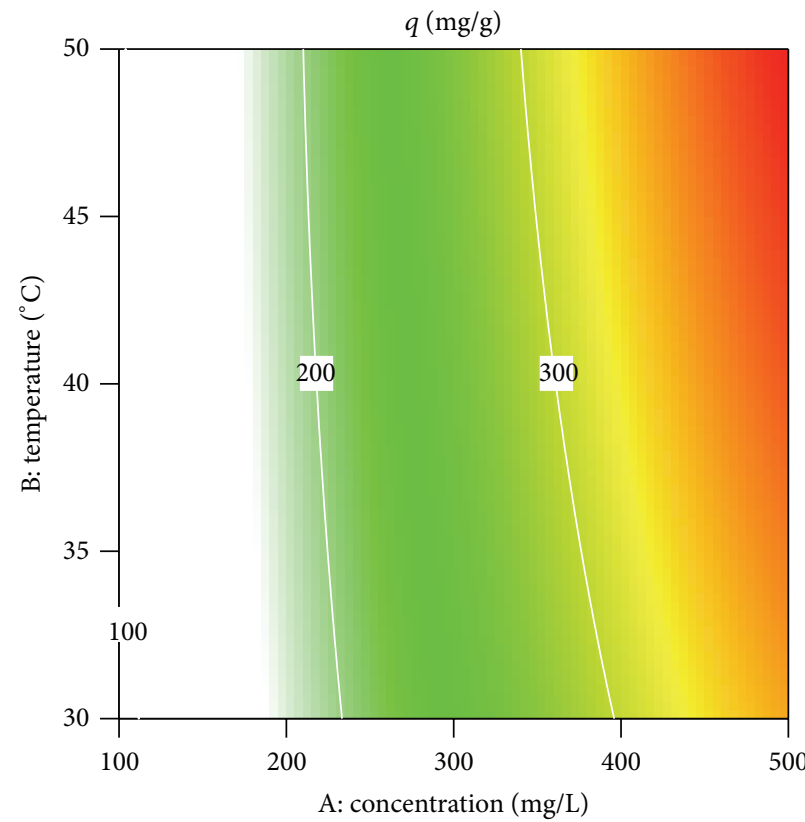

(a)

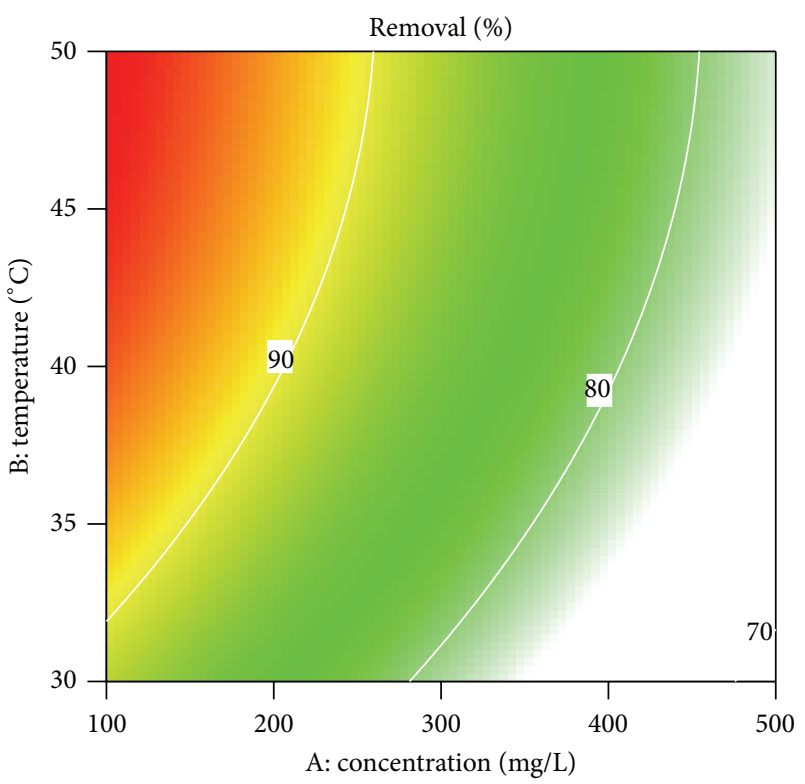

(b)

FIGURE 4: Two-dimensional contour plots: (a) combined effects of TB AGLF concentration and temperature on the adsorption capacity of sunflower pulp and (b) combined effects of TB AGLF concentration and temperature on percent TB AGLF removal by sunflower pulp.

be used to find adsorption capacity and dye removal \% in mixture containing unstudied concentrations of dye and temperature, yet extrapolation of these models to actual wastewater treatment systems is inappropriate. Investigations at an advance level are in progress for the analysis of adsorption of TB AGLF on sunflower pulp under various parameters, especially in presence of competing dye or metal ions. Moreover, in industrial applications, operation under continuous flow conditions (especially fixed bed reactors) is more preferred than a batch operation as continuous systems are able to be treated with large amount of wastewater. For a more adequate assessment of the sunflower pulp as an adsorbent, our study will continue to include continuous system operations in the presence of competing ions. Then, by 
TABLE 10: Kinetic model parameters for TB AGLF dye adsorption on sunflower pulp at different initial dye concentrations.

\begin{tabular}{lcccccc}
\hline \multirow{2}{*}{$C_{0}\left(\mathrm{mg} \mathrm{L}^{-1}\right)$} & $q_{e, \text { exp }}\left(\mathrm{mg} \mathrm{g}^{-1}\right)$ & \multicolumn{3}{c}{ The pseudo-first-order kinetic } & \multicolumn{2}{c}{ The pseudo-second-order kinetic } \\
& & $k_{1}(1 / \mathrm{min})$ & $q_{e, c}(\mathrm{mg} / \mathrm{g})$ & $R^{2}$ & $k_{2}(1 / \mathrm{min})$ & $q_{e, c}(\mathrm{mg} / \mathrm{g})$ \\
\hline 25 & 21.324 & 0.0083 & 20.241 & 0.9630 & 0.0022 & 20.143 \\
50 & 43.971 & 0.0124 & 43.470 & 0.9415 & 0.0012 & 0.9901 \\
75 & 69.779 & 0.0129 & 69.108 & 0.9561 & 0.0010 & 0.9834 \\
100 & 97.794 & 0.0131 & 96.923 & 0.9337 & 0.0013 & 67.196 \\
200 & 205.882 & 0.0131 & 204.055 & 0.9797 & 0.0004 & 95.664 \\
300 & 265.441 & 0.0117 & 261.574 & 0.9744 & 0.0002 & 0.9989 \\
500 & 393.382 & 0.0118 & 387.653 & 0.9833 & 0.0001 & 253.511 \\
\hline
\end{tabular}

taking into consideration the influences of these parameters, the most naturalistic models should be improved.

\section{Conflict of Interests}

The authors declare that there is no conflict of interests regarding the publication of this paper.

\section{References}

[1] A. Özcan, C.. Ömeroǧlu, Y. Erdoǧan, and A. S. Özcan, "Modification of bentonite with a cationic surfactant: an adsorption study of textile dye reactive blue 19," Journal of Hazardous Materials, vol. 140, no. 1-2, pp. 173-179, 2007.

[2] S. Wang and H. Li, "Dye adsorption on unburned carbon: kinetics and equilibrium," Journal of Hazardous Materials, vol. 126, no. 1-3, pp. 71-77, 2005.

[3] A. R. Gregory, J. Elliot, and P. Kluge, "Ames testing of direct black 38 parallels carcinogenicity testing," Journal of Applied Toxicology, vol. 1, no. 6, pp. 308-313, 1981.

[4] F. A. Pavan, S. L. P. Dias, E. C. Lima, and E. V. Benvenutti, "Removal of Congo red from aqueous solution by anilinepropylsilica xerogel," Dyes and Pigments, vol. 76, no. 1, pp. 64-69, 2008.

[5] C. Park, M. Lee, B. Lee et al., "Biodegradation and biosorption for decolorization of synthetic dyes by Funalia trogii," Biochemical Engineering Journal, vol. 36, no. 1, pp. 59-65, 2007.

[6] R. Gong, Y. Ding, M. Li, C. Yang, H. Liu, and Y. Sun, "Utilization of powdered peanut hull as biosorbent for removal of anionic dyes from aqueous solution," Dyes and Pigments, vol. 64, no. 3 , pp. 187-192, 2005.

[7] A. N. Ejhieh and M. Khorsandi, "Photodecolorization of eriochrome black $\mathrm{T}$ using NiS-P zeolite as a heterogeneous catalyst," Journal of Hazardous Materials, vol. 176, no. 1-3, pp. 629-637, 2010.

[8] E. Riyanto, N. Norazizi, and R. O. Mohamed, "Textiles industries wastewater treatment by electrochemical oxidation technique using metal plate," International Journal of Electrochemical Science, vol. 8, pp. 11403-11415, 2013.

[9] G. M. Shaul, T. J. Holdsworth, C. R. Dempsey, and K. A. Dostal, "Fate of water soluble azo dyes in the activated sludge process," Chemosphere, vol. 22, no. 1-2, pp. 107-119, 1991.

[10] V. M. Vučurović, R. N. Razmovski, U. D. Miljić, and V. S. Puškaš, "Removal of cationic and anionic azo dyes from aqueous solutions by adsorption on maize stem tissue," Journal of the
Taiwan Institute of Chemical Engineers, vol. 45, no. 4, pp. 17001708, 2014.

[11] A. E. Nemr, O. Abdelwahab, A. El-Sikaily, and A. Khaled, "Removal of direct blue- 86 from aqueous solution by new activated carbon developed from orange peel," Journal of Hazardous Materials, vol. 161, no. 1, pp. 102-110, 2009.

[12] P. S. Kumar, S. Ramalingam, C. Senthamarai, M. Niranjanaa, P. Vijayalakshmi, and S. Sivanesan, "Adsorption of dye from aqueous solution by cashew nut shell: studies on equilibrium isotherm, kinetics and thermodynamics of interactions," Desalination, vol. 261, no. 1-2, pp. 52-60, 2010.

[13] B. H. Hameed, "Evaluation of papaya seeds as a novel nonconventional low-cost adsorbent for removal of methylene blue," Journal of Hazardous Materials, vol. 162, no. 2-3, pp. 939944, 2009.

[14] C.-S. Zhu, L.-P. Wang, and W.-B. Chen, "Removal of $\mathrm{Cu}(\mathrm{II})$ from aqueous solution by agricultural by-product: peanut hull," Journal of Hazardous Materials, vol. 168, no. 2-3, pp. 739-746, 2009.

[15] A. Bhatnagar and M. Sillanpää, "Utilization of agro-industrial and municipal waste materials as potential adsorbents for water treatment-a review," Chemical Engineering Journal, vol. 157, no. 2-3, pp. 277-296, 2010.

[16] U. Farooq, J. A. Kozinski, M. A. Khan, and M. Athar, "Biosorption of heavy metal ions using wheat based biosorbents-a review of the recent literature," Bioresource Technology, vol. 101, no. 14, pp. 5043-5053, 2010.

[17] G. McKay, M. El-Geundi, and M. M. Nassar, "Equilibrium studies for the adsorption of dyes on bagasse pith," Adsorption Science and Technology, vol. 15, no. 4, pp. 251-270, 1997.

[18] S. D. Khattri and M. K. Singh, "Colour removal from dye wastewater using sugar cane dust as an adsorbent," Adsorption Science and Technology, vol. 17, no. 4, pp. 269-282, 1999.

[19] R. H. Myers and D. C. Montgomery, Response Surface Methodology, John Wiley \& Sons, New York, NY, USA, 2nd edition, 2002.

[20] K. Ravikumar, K. Pakshirajan, T. Swaminathan, and K. Balu, "Optimization of batch process parameters using response surface methodology for dye removal by a novel adsorbent," Chemical Engineering Journal, vol. 105, no. 3, pp. 131-138, 2005.

[21] S. V. İ. Srinivasan and D. V. S. Murthy, "Statistical optimization for decolorization of textile dyes using Trametes versicolor," Journal of Hazardous Materials, vol. 165, no. 1-3, pp. 909-914, 2009.

[22] K. P. Singh, S. Gupta, A. K. Singh, and S. Sinha, "Experimental design and response surface modeling for optimization of Rhodamine B removal from water by magnetic nanocomposite," Chemical Engineering Journal, vol. 165, no. 1, pp. 151-160, 2010. 
[23] F. Gönen and Z. Aksu, "Use of response surface methodology (RSM) in the evaluation of growth and copper(II) bioaccumulation properties of Candida utilis in molasses medium," Journal of Hazardous Materials, vol. 154, no. 1-3, pp. 731-738, 2008.

[24] I. K. Kapdan, F. Kargia, G. McMullan, and R. Marchant, "Effect of environmental conditions on biological decolorization of textile dyestuff by C. versicolor," Enzyme and Microbial Technology, vol. 26, no. 5-6, pp. 381-387, 2000.

[25] N. Hatvani and I. Mécs, "Effects of certain heavy metals on the growth, dye decolorization, and enzyme activity of Lentinula edodes," Ecotoxicology and Environmental Safety, vol. 55, no. 2, pp. 199-203, 2003.

[26] S. Lagergren, Zur Theorie der Sogenannten Adsorption Gelöster Stoffe, Kungliga, 1898.

[27] Y. S. Ho and G. McKay, "Sorption of dye from aqueous solution by peat," Chemical Engineering Journal, vol. 70, no. 2, pp. 115124, 1998.

[28] P. Senthil Kumar, S. Ramalingam, C. Senthamarai, M. Niranjanaa, P. Vijayalakshmi, and S. Sivanesan, "Adsorption of dye from aqueous solution by Cashew nut shell: studies on equilibrium isotherm, kinetics and thermodynamics of interactions," Desalination, vol. 261, no. 1-2, pp. 52-60, 2010.

[29] N. Thinakaran, P. Baskaralingam, M. Pulikesi, P. Panneerselvam, and S. Sivanesan, "Removal of Acid Violet 17 from aqueous solutions by adsorption onto activated carbon prepared from sunflower seed hull," Journal of Hazardous Materials, vol. 151, no. 2-3, pp. 316-322, 2008.

[30] M. Arami, N. Y. Limaee, N. M. Mahmoodi, and N. S. Tabrizi, "Equilibrium and kinetics studies for the adsorption of direct and acid dyes from aqueous solution by soy meal hull," Journal of Hazardous Materials, vol. 135, no. 1-3, pp. 171-179, 2006.

[31] F. Ghorbani, H. Younesi, S. M. Ghasempouri, A. A. Zinatizadeh, M. Amini, and A. Daneshi, "Application of response surface methodology for optimization of cadmium biosorption in an aqueous solution by Saccharomyces cerevisiae," Chemical Engineering Journal, vol. 145, no. 2, pp. 267-275, 2008.

[32] V. Vadivelan and K. V. Kumar, "Equilibrium, kinetics, mechanism, and process design for the sorption of methylene blue onto rice husk," Journal of Colloid and Interface Science, vol. 286, no. 1, pp. 90-100, 2005.

[33] M. C. Ncibi, B. Mahjoub, and M. Seffen, "Kinetic and equilibrium studies of methylene blue biosorption by Posidonia oceanica (L.) fibres," Journal of Hazardous Materials, vol. 139, no. 2, pp. 280-285, 2007.

[34] A. Usluoglu, E. Altintig, and G. Arabaci, "Characterization of activated carbon prepared from agricultural waste and its applications for decolorization of textile dyes," Current Opinion in Biotechnology, vol. 24, pp. S75-S76, 2013.

[35] S. Karimifard and M. R. A. Moghaddam, "Enhancing the adsorption performance of carbon nanotubes with a multistep functionalization method: optimization of Reactive Blue 19 removal through response surface methodology," Process Safety and Environmental Protection, vol. 99, pp. 20-29, 2016.

[36] S. V. Srinivasan and D. V. S. Murthy, "Statistical optimization for decolorization of textile dyes using Trametes versicolor," Journal of Hazardous Materials, vol. 165, no. 1-3, pp. 909-914, 2009. 

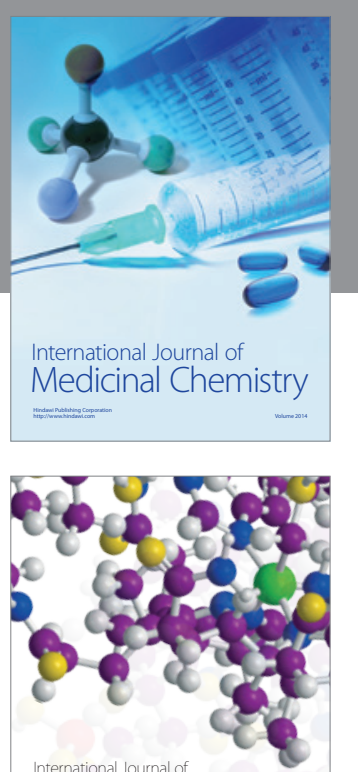

Carbohydrate Chemistry

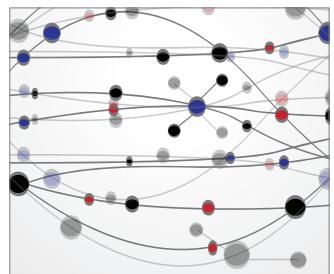

The Scientific World Journal
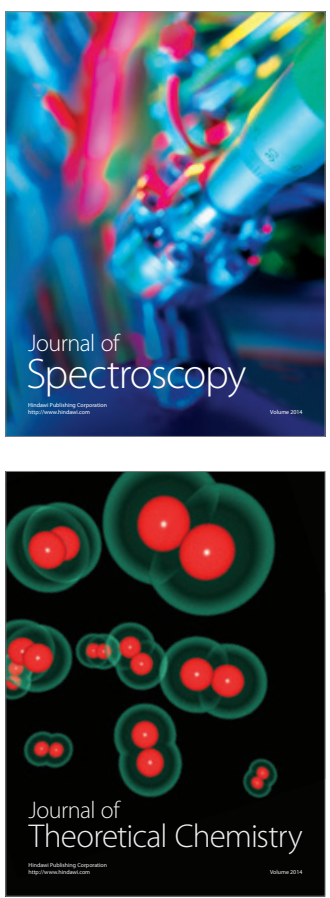
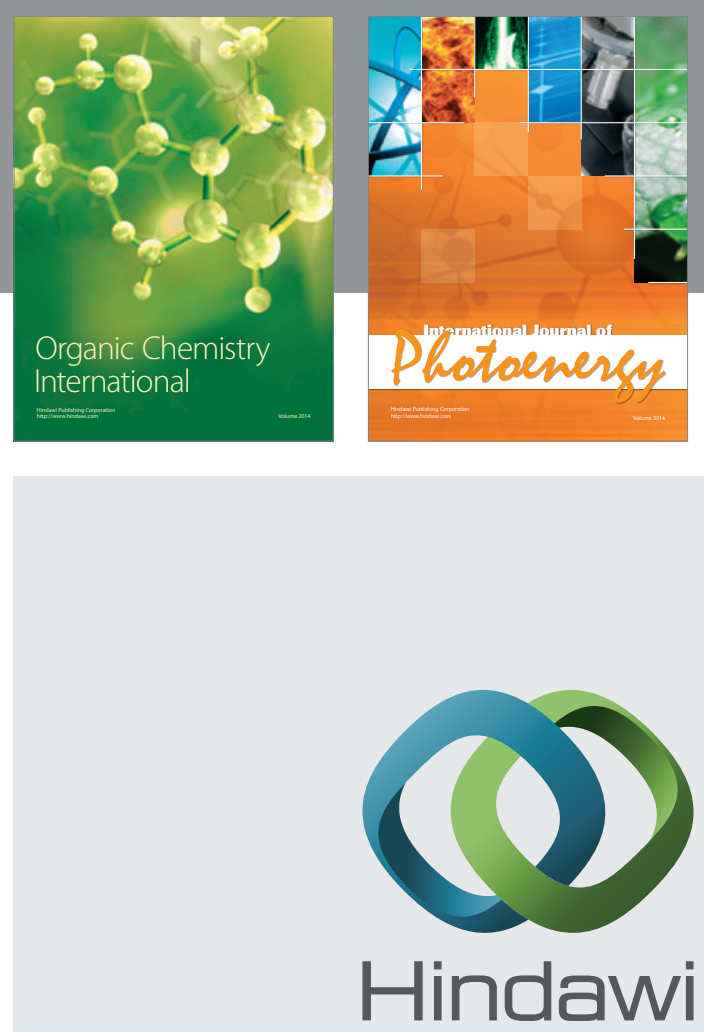

Submit your manuscripts at

http://www.hindawi.com

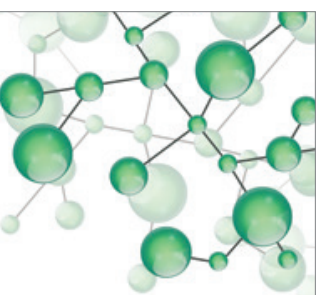

International Journal of

Inorganic Chemistry

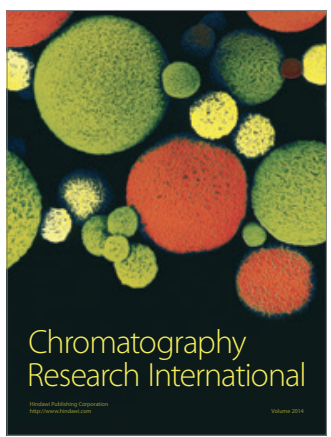

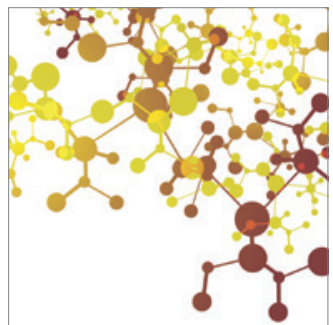

Applied Chemistry
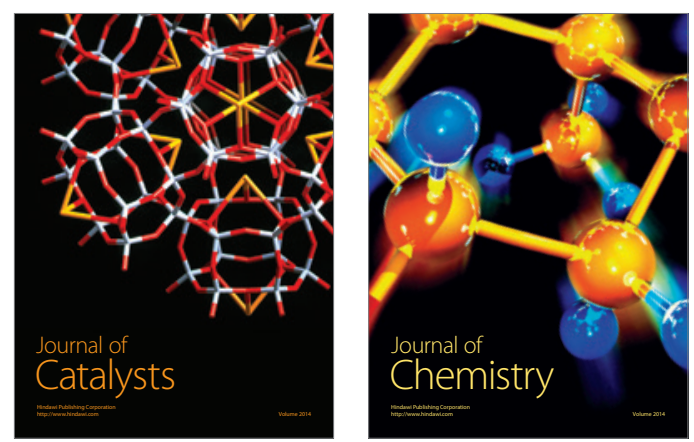
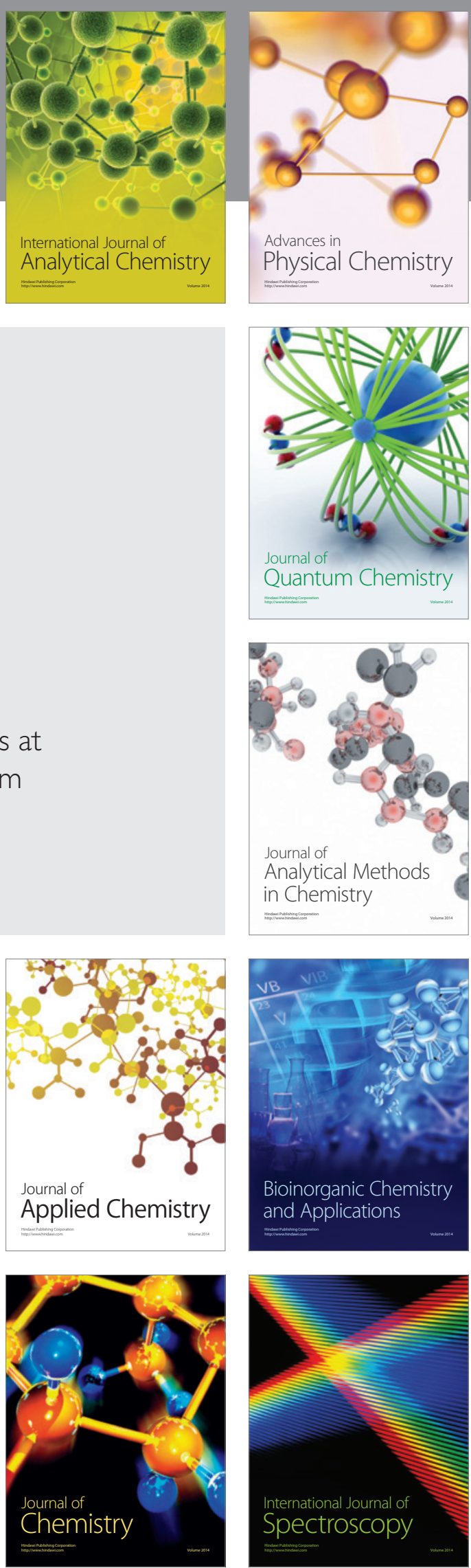